The commonest species are Trigonia irregularis Seebach, T. elongata Sow., Liostrea undosa (Phil.) and Lopha marshii (Sow.), with numerous fragments of flattened Proplanulites, some having Serpulae attached.

Many of the Trigoniae are broken, but large numbers, although very fragile, are whole and unworn, and may be collected in an exceptionally perfect state of preservation. The nearest point at which Callovian or higher beds touch the shore is distant 2 miles in one direction and $2 \frac{1}{2}$ miles in the other. It is inconceivable that any of the fossils can have travelled 2 miles along the coast without becoming broken or worn. Moreover, on their journey they would have to pass localities where the shore is covered with Cornbrash fossils, and others where it is almost made of Bradfordian brachiopods from the Rhynchonella boueti Bed, yet they have collected none of these on their way, nor have they left any trail along the intervening beaches. Long-shore drift in the Fleet is, in fact, so slight that the outcropping fossil-beds contaminate only small areas.

The inference seems justifiable, even unavoidable, that opposite this point on the coast there is a submerged tract of Kellaways Beds faulted down against the middle of the Fullers Earth. As few of the pebbles from the Chesil Beach cross the Fleet to the opposite shore, it is likely that the shells are being weathered out of the bed of the backwater.

Incidentally, the locality provides a striking illustration of how mistakes may have crept into old records. These shells have obviously come from a clay matrix and they lie upon a clay foreshore, in which other oysters may be seen in situ. What more natural than to regard them all as belonging to the Fullers Earth?

14 Chadlington Road,

W. J. Arkell.

OXFORD.

\title{
THE CLAY PEBBLE BED OF ANCON, ECUADOR.
}

Sir,-Dr. Busk's letter in your May issue having reopened the discussion concerning the origin of the Clay Pebble Bed of Ancon, Ecuador, I should like to state that after ten years' study of the tectonics of north-west Peru I have proved beyond doubt that the Tertiary Rocks from Payta in Peru to the Santa Elena Peninsula in Ecuador have slipped down the steep slope on which they were deposited. This conclusion is based on several hundred square miles of large scale geological mapping and the examination of 800 well logs representing 1,700,000 feet of drilling.

The result is, as Dr. Busk states, a gigantic tectonic breccia, at least 200 miles long and 20 miles wide. Clay Pebble Beds are common throughout, though that at Ancon is the best example.

The movement has taken place along huge slip planes, which are in every way similar to thrust planes except that they are normal faults of low angle instead of reversed faults, so that instead of 
repetition of strata there is elimination of several thousand feet. The lateral shift of $5 \mathrm{~km}$. mentioned by Dr. Busk is of similar magnitude to numerous examples I have studied, and the total slip of the uppermost strata over the lowest must be at least 10 miles.

The "thrust plane" of our original paper is undoubtedly one of these slip planes, which I hope to describe in detail when I return to England next year.

LoBITOS,

R. A. BALDRY.

Talara,

Peru.

2nd August, 1931.

\section{COAL MEASURE FLORAS.}

SIR,-I should like to be allowed to draw attention to the important conclusions reached by Dr. R. Crookall in his recent "Critical Revision of Kidston's Coal Measure Floras" (Proc. Roy. Phys. Soc., xxii, 1931, p. 1). The supposed absence of any equivalent of the Lanarkian Series in South Wales, maintained on palaeobotanical evidence, has been disputed by workers on both marine and nonmarine faunas, and it is gratifying to find that Dr. Crookall now recognizes that its supposed absence was due to inadequate collecting, Dr. Crookall also shows that a portion of Kidston's Westphalian (now known as Yorkian) in Yorkshire is equivalent to a portion of his Lanarkian in Scotland. Similar conclusions have been reached independently by Miss E. Dix, and it therefore appears that there is no serious discrepancy in the correlations based on faunas and floras (cf. Dix, Pringle, and Trueman, The Naturalist, 1930, p. 324).

Dr. Crookall proposes for the present to retain Kidston's term Lanarkian and to include in it, broadly, the Lower Coal Measures and Millstone Grit of Yorkshire and their equivalents. He would place the top of the Lanarkian in Stirlingshire at approximately the level of the Auchingane Coal, whereas Kidston in 1916 selected the Ell Coal ; this change involves transferring to the Yorkian about three-quarters of those Scottish Coal Measures which Kidston placed in his Lanarkian, and at the same time transferring to the Yorkian a great number of the records which constituted Kidston's Lanarkian flora. It is apparent that Kidston's term Lanarkian was ill-defined, both palaeontologically and stratigraphically, and has already led to much confusion; I hope Dr. Crookall will agree to a revised terminology when the sequence is sufficiently known.

\section{University College, \\ SWANSEA.}

A. E. Trueman.

4th October, 1931.

[As the above letter suggests a revision of Coal-measure terminology, the Editor, as a Yorkshireman, ventures to express his 